\title{
A Study of Financial Development Impact on Economic Growth: A Comparison Between Egypt and Saudi Arabia
}

\author{
Dirar Abdul-Hamid Al-Toum Al-Otaibi ${ }^{1}$, Hossam Hosney Abdul Aziz ${ }^{2}$ \& Shady Mohamed Shawky \\ Abdel-mawgoud ${ }^{3}$ \\ ${ }^{1}$ Assistant Professor, Department of Business Administration, College of Administrative and Financial Sciences, \\ King Khalid University, Saudia Arabia \\ ${ }^{2}$ Assistant Professor, Agricultural Research Center, Agricultural Economy Research Institute, Egypt \\ ${ }^{3}$ Assistant Professor, Faculty of Agriculture, Agricultural Economics Department, Menoufia University, Egypt \\ Correspondence: Dirar Abdul-Hamid Al-Toum Al-Otaibi, Assistant Professor, Department of Business \\ Administration, College of Administrative and Financial Sciences, King Khalid University, Saudia Arabia. E-mail: \\ Dalotaibi@kku.edu.sa
}

Received: April 26, 2021

doi:10.5430/rwe.v12n4p94
Accepted: June 4, 2021

Online Published: December 13, 2021

URL: https://doi.org/10.5430/rwe.v12n4p94

\begin{abstract}
Economic growth is always seen as one of the chief economic goals countries try to achieve, in order to develop its economics. Economic growth takes different forms following the varying economic theories, and it's mostly defined as achieving increase in average share of individual from the real gross national income at certain time period. One of the most frequently used indexes to measure economic growth is: Measuring economic growth based on the expected - no the real - income, especially in countries that possess rich resources. And based on gross domestic product at fixed price and one year, and the average individual share from real income.
\end{abstract}

Keywords: economic growth, financial development, Egypt, Saudi Arabia

\section{Introduction}

Fiscal and financial sector is aiming at raising economic indexes, through optimal assigning of financial resources and leveraging its economic revenue. As financial resources are deemed one of the factors that affect boosting productivity, savings rates, investment decisions, tech innovations and growth rates on the long run. It allows investment chances to people with financial deficit who are able to invest, thus, pushes forward the economic activity wheel. Therefore, banking sector is playing an important role in stimulating economic growth, through directing funds toward channels stimulating economic growth. There are variant opinions on basic elements shaping optimal financial structure that encourages economic growth on the long run which are bank, markets, financial services, financing and law regardless the relative importance of its different components and its development(Dolar \& Meh, 2002; Levine, 2005), Some studies have focused on the importance of the role played by financial development in speeding up economic growth, and stressed on the need of liberating financial system which contributes to increasing the amount of financial saving and the assignment of capitals to more productive purposes and contributing to economic growth (Lucas Jr, 1988; Rostow, 1974). While others believe (Robinson, 1979) that economic growth is the road to financial development, thus debate on the relationship between financial development and economic growth has become a subject to several studies that have led to different conclusions.

\subsection{Importance of the Research}

Stems from economic plans implemented by countries to achieve the positive impact of financial development in raising contribution rates of industrial sectors in forming gross domestic product through impacting different economic variables in general and economic growth in particular, whether on the short or the long run. Thus, studying financial development and measuring its impact on economic growth is considered one of the subjects that require permanent studying and evaluation.

\subsection{Research Problem}

It's reflected in the main question: At what extent financial development affects economic growth rates? And this is 
depending on the following hypotheses:

1) There's a statistically significant direct relationship on the long run between bank credit and financial development (As dependant variable).

2) There's a statistically significant inverse relationship on the long run between lending rate prices and financial development (As dependant variable).

3) There's a statistically significant direct relationship on the long run between inflation rate and financial development (As dependant variable).

4) There's a statistically significant direct relationship on the long run between money supply and financial development (As dependant variable).

\subsection{Research Objective}

The research basically targets measuring and analyzing the impact of financial development on economic growth, through measuring the short term and long-term relations between financial development and economic growth variables in a comparative study between Egyptian and Saudi economies, considering that both are different with regard to the foundations used to affect economic growth, using annual data represents the period (1980-2018).

\section{Method}

Autoregressive Distributed Lag Model (ARDL) methodology(Pesaran \& Shin, 1995; Pesaran, Shin, \& Smith, 2001) has been used, and it's considered more powerful for small samples that include 30-80 views. And it's used no matter whether decline is from rank I (0) or rank I (1), or in the case of mixing both of them. Short term and long-term relation can also be estimated at the same time, and it provides unbiased and competent evaluation. It's also more suitable for a model depending on one equation, and it helps in eliminating problems related to variable deletion and autocorrelation.

\subsection{Study Variables and Data Sources}

This study is concerned with realizing the impact of financial development on economic growth in both Egypt and Saudi Arabia as a comparative study between two different forms of economics during the period (1980-2018). These variables have been chosen based on economic theory and former studies, like: Economic growth (RGDP) where gross domestic product has been used (In fixed rates of local currency in 2010), bank credit (BC) where net domestic credit has been used (In current rates of local currencies), Lending interest rate (LIR), inflation rate (INF) where inflation has been used represented in rates paid by consumers (\% annually), broad money where money supply is used in broad meaning (In current rates of local currency).

\subsection{Description of Study Variables}

Indicator $\{$ GDP (In fixed rates of local currency) $\}$ Gross Domestic Product is the total sum of added value from all resident producers in an economy, plus any taxes imposed on products and minus any subsidies not included in products value. It's calculated without deducting the value of depreciation of manufactured assets or imposing any deductions due to natural resources depletion or deterioration. Data are in fixed rate of local currency.

Indicator $\{$ Net domestic credit (in current local currency rates) $\}$ Net Local Credit is the total of net credit supplied to non-financial public sector institutions, and credit directed to private sector institutions, and other accounts. Data are in current value of local currency.

Indicator $\{$ Lending interest rate $(\%)$ \} Lending Interest Rate is the rate received by banks on loans provided to primary clients.

Indicator \{Inflation, prices paid by consumers (annual percent) $\}$ Inflation reflects, as measured by consumer prices index, the annual change of percentage of cost incurred by average consumer to obtain a basket of goods and services that could be fixed or variable over a specific time period; for example, every year. Laspeyres formula is used in general

Indicator $\{$ Broad money supply (in current local currency rates)\} Broad Money (International financial statistics, row: L.Zk35) is sum of currency outside banks, demand deposits other than central governmental deposits; time deposits, savings, deposits in foreign currency for resident sectors other than central government; bank drafts and traveler's cheque; and financials items like tradable deposite certificates and trade papers. 


\subsection{Previous Studies}

Vaithilingam, Guru, \& Shanmugam (2003) explore Causality between commercial bank credit and economic growth in Malaysia, using Granger causality, the result indicates that an increase in commercial bank loans to the private sector has a direct effect on real income. Dritsakis \& Adamopoulos (2004) empirically examines the causal relationship between the degree of openness of the economy, financial development and economic growth in Greece, using multivariate autoregressive VAR model, the result indicates that cointegrated vector among GDP, financial development and the degree of openness of the economy, moreover, not only there is a causal relationship between financial development and economic growth, but also between the degree of openness of the economy and economic growth. Odhiambo (2005) assessed the role of Financial Development and Economic Growth in Tanzania: A Dynamic Casualty Test, The role of financial development in economic growth in Tanzania, using Cointegration test: Johansen Method and Vector Error Correction Model (VECM)) the result shows that Bidirectional losses exist between financial development and economic growth in Tanzania. Furqani \& Mulyany (2009) examines the dynamic interactions between Islamic banking and economic growth of Malaysia, using Cointegration test and Vector Error Model (VECM), the result shows that in short-run only fixed investment that granger cause Islamic bank to develop and in the long-run, there is evidence of a bidirectional relationship between Islamic bank and fixed investment and there is evidence to support demand following hypothesis of GDP and Islamic bank, where increase in GDP causes Islamic banking to develop and not vice versa. Perera \& Paudel (2009) explore the causal relationship between financial development and economic growth in SriLanka, using Cointegration test: Johansen Method, Error Correction Model (VECM), the result indicates that broad money causes economic growth with two-way causality. The major finding of this study does not strongly support the view that financial development boosts economic growth. Adamopoulos (2010) examines the relationship between financial development and economic growth for Ireland, using Vector Error Correction Model (VECM), Cointegration test: Johansen Method and Granger causality tests, the result shows that Credit market development is a result of economic growth. There's causality relationship in the two direction between stock market development and economic growth. Thus, it can be concluded that economic growth has a positive impact on stock market development and credit market development, putting in mind the positive impact of industrial production growth on economic growth in Ireland. Antonios (2010) explore investigated the causal relationship between credit market development and economic growth for Ireland, using Vector Error Correction Model (VECM), the result shows that unidirectional causality between credit market development and economic growth for Ireland. Shaheen, Awan, Waqas, \& Aslam (2011) Study examines the relationship between financial development and economic growth in the United Kingdom. Using Vector Error Correction Model (VECM), Cointegration test: Johansen Method and Granger causality tests, the result suggests that a causal relationship between financial development and economic growth in the United Kingdom. Shaheen et al. (2011) examines Discovery of a long-term equilibrium relationship and possible causality direction between international trade and financial development and economic growth in Pakistan, using Autoregressive Distributed Lags (ARDL) approach, the result indicates that Existence of long-term relationship between variables in Pakistan, and a one-way relationship from international trade to economic growth, and from financial development to international trade. Leitão (2012) explore A relationship between bank credit and economic growth in the EU. Using A Dynamic Panel Data. the result indicates that Bank credit and inflation have negative impact on economic growth, while savings boost it. Ogunyiola (2013) examines the relationship between financial development and economic growth, in the long and short term, in Cape Verde, Using Vector Error Correction Model (VECM), the result shows that Existence of a long-term relationship between economic growth and financial development. There're no relationships between economic growth and financial development on the short-term. A one-way relationship has been found from financial development to economic growth at money supply (M2). Existence of causality relationship in two directions between financial development and economic growth when loans are given from commercial banks. Study has also found out a one-way causality relationship from economic growth to local credit in private sector. Judith, Ugwuegbe, \& Ugwuoke (2014) empirically examine The Impact of Bank Credit on Economic Growth in Nigeria, using Error Correction Model (VECM), the result indicates that the Long-term bank credit has a negative and significant impact on economic growth in Nigeria, the reason behind that is banking sector in Nigeria doesn't support the most active sectors in economy. While in short-term, bank credit has no impacts on economic growth, while money supply has a positive and significant impact on economic growth. Osman (2014) Analyzing the relationship between the two credits offered by commercial banks and economic growth in Saudi Arabia, using Autoregressive Distributed Lags (ARDL) approach, the result indicates that Existence of a significant and direct relationship between bank credits and economic growth on the long term, this is explained by good management of Saudi banks to its financial resources, through assigning it to big investments that boost economic growth. Tabash \& Dhankar (2014) Evaluating the impact of Islamic banks financing on economic growth in UAE, 
using Unit root test, Cointegration test: Johansen Method and Granger causality tests, the result shows that There's a strong positive relationship between Islamic banks financing and economic growth. There's a causality relationship occurring in one direction from Islamic bank financing to economic growth. There's a long-term stable relationship between Islamic banks financing and economic growth in UAE, which means that Islamic banks financing and economic growth move together on the long term. Gautam (2014) examines the relationship between economic growth and financial development in Nepal, using Unit root test, Cointegration test: Johansen Method, Granger causality tests and Vector Error Correction Model (VECM), the result suggests that Financial development is a reason of economic growth on the short run, while economic growth contributes to boosting financial development in the long run. Musamali, Nyamongo, \& Moyi (2014) examines the relationship between financial development and economic growth, using Panel unit root tests, Causality Tests and Pooled and fixed effects estimation, the result suggests that both the financial sector and the real sector are important in influencing Africa's current and future growth trajectory. Duican \& Pop (2015) explore the relationship between bank credit and economic growth in Romania, using A Dynamic Panel Data, the result shows that the Bank credit has a major influence on the development of real GDP. Tahir, Shehzadi, Ali, \& Ullah (2015) examines the association among bank credit to private sector and economic growth in Pakistan, using co-integration VECUM and Granger causality tests, the result indicates that the bank credit had extensive relationship with economic progression; in short term the relationship was also significant. Regression analysis showed that there was adverse impact of bank credit on economic growth in Pakistan. Mohanty, Kumar, \& Patra (2016) explore the effect of bank credit on economic growth in Indian states, using The Panel Causality Model and A Dynamic Panel Data, the result indicates that There's Existence of two-way relationship between bank credit and economic growth. Bank credits, capital expenditures and development expense all have positive impact on economic growth. Guptha $\&$ Rao (2018) about determine whether the development of the financial system in these economies is the cause for their growth, using principal component analysis and TodaYamamoto causality test, the result shows that There's no uniformity in finance and growth causality among the BRICS countries. Uttam Paudel (2018) explore the impact and direction of causality between financial development and economic growth, using Unit root test, Engle-Granger, co-integration test and Error correction model, the result shows that although finance led growth yields positive consequences, real sectors indicator like consumer price index (CPI) has more impact on real gross domestic product (GDP), a proxy of economic growth, than financial development indicators (M2Y, CPY) in Nepal. Mwang'onda, Mwaseba, \& Ngwilizi (2018) empirically examine the impact of financial sector on economic growth of Tanzania, using Autoregressive Distributed Lags (ARDL) approach, in both long-run and short-run, financial development exerts significant but negative effect on economic growth, the result suggests that in both long-run and short-run, financial development exerts significant but negative effect on economic growth nonexistence of causality between financial development and economic growth nonexistence of causality between financial development and economic growth.

\section{Results and Discussion}

\subsection{Trend and Graph}

Table 2 that shows graph and trend of variables time series being discussed points out that they're significant for Egypt with regard to all variables except inflation rate (Significant in the intercept), in addition to the non-significance of inflation rate. Graph and trend are useful in choosing the proper formula in stationary tests whether without trend and intercept, with intercept only, or with trend and intercept. This will be done through the nature of study series based on existence of any of trend and intercept, or both(Lee \& Chien, 2008). 
Table 1. Graph and trend of Egypt and Saudi Arabia during the period 1980 (1980-2019)

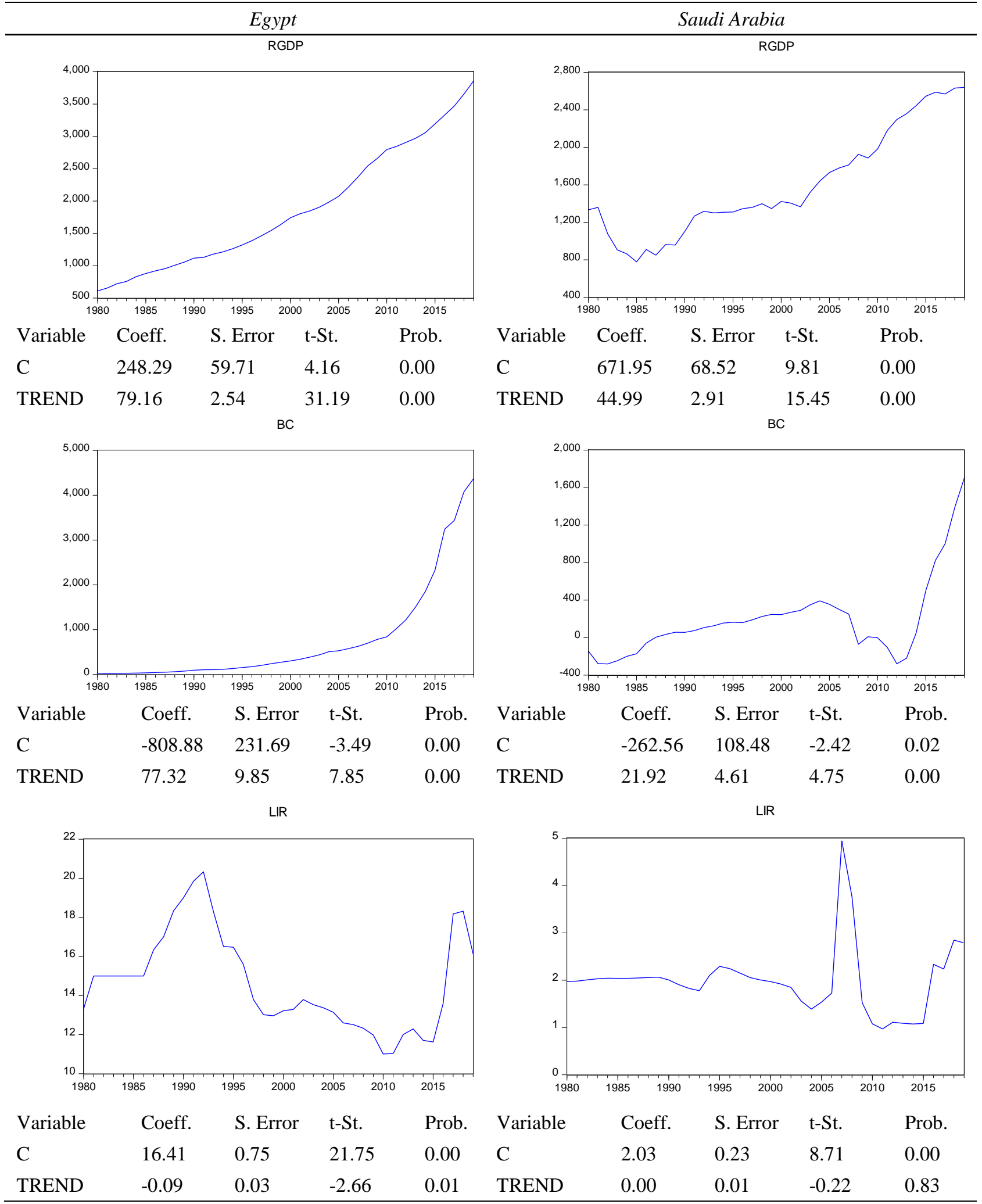


INF

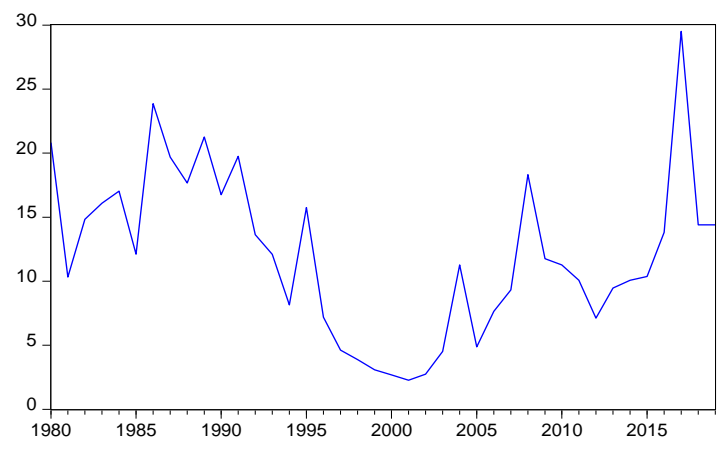

INF

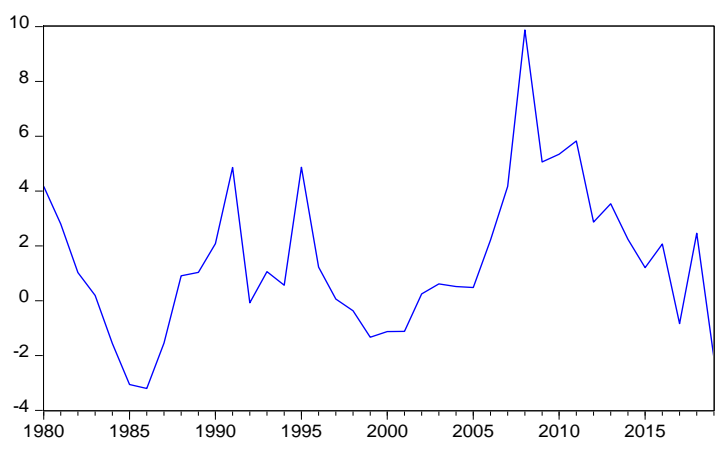

$\begin{array}{llllllllll}\text { Variable } & \text { Coeff. } & \text { S. Error } & \text { t-St. } & \text { Prob. } & \text { Variable } & \text { Coeff. } & \text { S. Error } & \text { t-St. } & \text { Prob. } \\ \text { C } & 14.74 & 2.03 & 7.28 & 0.00 & \text { C } & 0.18 & 0.84 & 0.21 & 0.83 \\ \text { TREND } & -0.13 & 0.09 & -1.49 & 0.15 & \text { TREND } & 0.06 & 0.04 & 1.70 & 0.10\end{array}$
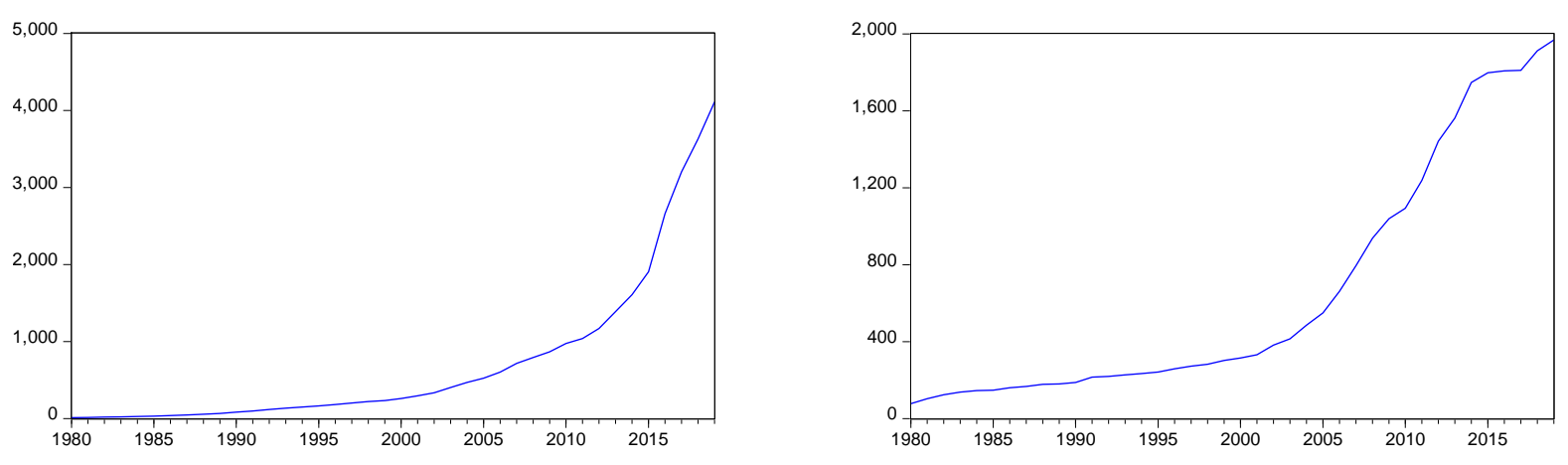

Variable Coeff. S. Error t-St. Prob. Variable

Coeff. S. Error t-St. Prob.

$\begin{array}{llllll}\text { C } & -728.09 & 202.14 & -3.60 & 0.00 & \text { C }\end{array}$

$\begin{array}{llllll}\text { TREND } & 70.69 & 8.59 & 8.23 & 0.00 & \text { TREND }\end{array}$

$-338.48$

89.59

$-3.78$

0.00

Source: Prepared by researchers using EVIEWS 10.

\subsection{Stationary Test}

Stationary test aims to recognize the integration of study time series in order to select the proper model to evaluate the relation between study variables, while eliminating spurious regression. Table 3 illustrates 3 tests to confirm time series stationary - in the light of trend conclusions in Table 2 - where Phillips \& Perron (1988) PP test, that depends on ADF model, was used along with the use of non-parametrically modified. And ADF Augmented Dickey-Fuller (1979) test that depends on First order autoregression, and also the KPSS test got both Kwiatkowski-Phillips-Schmidt-Shin (1992), (Fedorová, 2016). Tests that were used have confirmed the acceptance of null hypotheses with stability of variables that've been studied at the different levels of significance, whether at Level I(0) or at First Difference I(1) with difference for some variables in case of Egypt and Saudi Arabia. This leads to a conclusion that time series of study variables is a mixture of integrated series from level zero $\mathrm{I}(0)$, and other integrated from level one I(1), consequently Autoregressive Distributed Lag Model (ARDL) is the most proper one to estimate the relation among variables (Pesaran et al., 2001). 
Table 2. UNIT ROOT TEST Results

\begin{tabular}{|c|c|c|c|c|c|c|c|c|c|c|c|}
\hline \multirow{2}{*}{\multicolumn{2}{|c|}{ At Level }} & \multicolumn{5}{|c|}{ Egypt } & \multicolumn{5}{|c|}{ Saudi Arabia } \\
\hline & & RGDP $^{(a)}$ & $\mathrm{BC}^{(\mathrm{a})}$ & $\operatorname{LIR}^{(\mathrm{a})}$ & $\mathrm{INF}^{(\mathrm{b})}$ & $\mathrm{M} 2^{(\mathrm{a})}$ & $\mathrm{RGDP}^{(\mathrm{a})}$ & $\mathrm{BC}^{(\mathrm{a})}$ & $\mathrm{LIR}^{(\mathrm{b})}$ & $\mathrm{INF}^{(\mathrm{c})}$ & $\mathrm{M} 2^{(\mathrm{a})}$ \\
\hline \multirow[t]{3}{*}{ PP } & $\mathrm{t}-\mathrm{St}$. & 0.57 & 3.90 & -1.88 & -3.30 & 6.82 & -3.31 & -0.45 & -2.95 & -2.75 & -0.71 \\
\hline & Prob. & 1.00 & 1.00 & 0.65 & 0.02 & 1.00 & 0.08 & 0.98 & 0.05 & 0.01 & 0.97 \\
\hline & & n0 & no & no & $* *$ & n0 & $*$ & no & $* *$ & *** & no \\
\hline \multirow[t]{3}{*}{$\mathrm{ADF}$} & $\mathrm{t}-\mathrm{St}$. & 0.70 & 2.96 & -1.92 & -3.28 & 1.59 & -3.35 & -3.75 & -4.21 & -2.72 & -1.29 \\
\hline & Prob. & 1.00 & 1.00 & 0.63 & 0.02 & 1.00 & 0.07 & 0.03 & 0.00 & 0.01 & 0.88 \\
\hline & & n0 & n0 & n0 & $* *$ & n0 & $*$ & $* *$ & $* * *$ & $* * *$ & n0 \\
\hline \multirow[t]{2}{*}{ KPSS } & t-St. & 0.21 & 0.18 & 0.11 & 0.24 & 0.20 & 0.19 & 0.09 & 0.04 & & 0.19 \\
\hline & Prob. & $* *$ & $* *$ & no & no & $* *$ & $* *$ & no & no & & $* *$ \\
\hline \multicolumn{2}{|c|}{$\begin{array}{l}\text { At First } \\
\text { Difference }\end{array}$} & $\mathrm{d}(\mathrm{RGDP})$ & $\mathrm{d}(\mathrm{BC})$ & d(LIR) & $\mathrm{d}(\mathrm{INF})$ & $\mathrm{d}(\mathrm{M} 2)$ & d(RGDP) & $\mathrm{d}(\mathrm{BC})$ & d(LIR) & $\mathrm{d}(\mathrm{INF})$ & $\mathrm{d}(\mathrm{M} 2)$ \\
\hline \multirow[t]{3}{*}{ PP } & t-St. & -2.53 & -4.68 & -3.12 & -10.5 & -2.07 & -5.07 & -2.78 & -9.19 & -8.15 & -3.17 \\
\hline & Prob. & 0.31 & 0.00 & 0.12 & 0.00 & 0.54 & 0.00 & 0.21 & 0.00 & 0.00 & 0.11 \\
\hline & & $\mathrm{n} 0$ & $* * *$ & $\mathrm{n} 0$ & $* * *$ & n0 & $* * *$ & $\mathrm{n} 0$ & $* * *$ & $* * *$ & $\mathrm{n} 0$ \\
\hline \multirow[t]{3}{*}{$\mathrm{ADF}$} & t-St. & -3.83 & -6.07 & -4.58 & -9.75 & 3.38 & -4.98 & -2.78 & -5.87 & -8.15 & -3.20 \\
\hline & Prob. & 0.03 & 0.00 & 0.00 & 0.00 & 1.00 & 0.00 & 0.21 & 0.00 & 0.00 & 0.10 \\
\hline & & $* *$ & $* * *$ & $* * *$ & $* * *$ & n0 & $* * *$ & $\mathrm{n} 0$ & $* * *$ & $* * *$ & $*$ \\
\hline \multirow[t]{2}{*}{ KPSS } & t-St. & 0.07 & 0.17 & 0.12 & 0.24 & 0.17 & 0.10 & 0.13 & 0.31 & & 0.10 \\
\hline & Prob. & n0 & $* *$ & $*$ & n0 & $* *$ & n0 & $*$ & n0 & & $\mathrm{n} 0$ \\
\hline
\end{tabular}

Source: Prepared by researchers using EVIEWS 10.

Model specification: (a) With Constant \& Trend, (b) With Constant, (c) Without Constant \& Trend

(*) Significant at the $10 \%,(* *)$ Significant at the 5\%,(***) Significant at the $1 \%$. and (no) Not Significant

- MacKinnon (1996) one-sided p-values for PP and ADF.

- Lag Length based on SIC, Probability based on Kwiatkowski-Phillips-Schmidt-Shin (1992, Table 1) for KPSS.

\subsection{Model Initial Estimation and Validity Test}

Model initial estimation has been made at four degrees of auto delay. And in order to test the estimated model with regard to instability and misspecification, two tests have been considered, Ramsey RESET Test, CUSUM of Squares (Ramsey, 1969). It turned out that estimated model suffers from instability and misspecification problem, as per Table 4 and according to CUSUM of Squares test for Egypt and Saudi Arabia, there are regression residuals outside critical limits of random error. Consequently, model parameters were unstable, add to that - in case of Saudi Arabia - the significance of Ramsey RESET Test. As a result, the estimated model suffers from a misconception problem.

As it's shown in table 5 that's concerned with conclusions of tests of residuals series, represented in Serial Correlation LM test (Breusch, 1978), Heteroskedasticity Test (Breusch \& Pagan, 1979) (Engle, 1982), and Normality Test (Breusch \& Pagan, 1979), that Egypt model suffers from an autocorrelation problem due to the statistical significance of Breusch-Godfrey test. That indicates the rejection of null hypotheses, so the residuals series suffers from the autocorrelation problem. While Saudi model suffers from a heteroscedasticity problem due to significance of ARCH test, which indicates the rejection of null hypotheses. So, the residuals series suffers from a heteroscedasticity problem. Thus, the two models do not have the characteristic of Econometric Robustness. 
Table 3. Stability tests

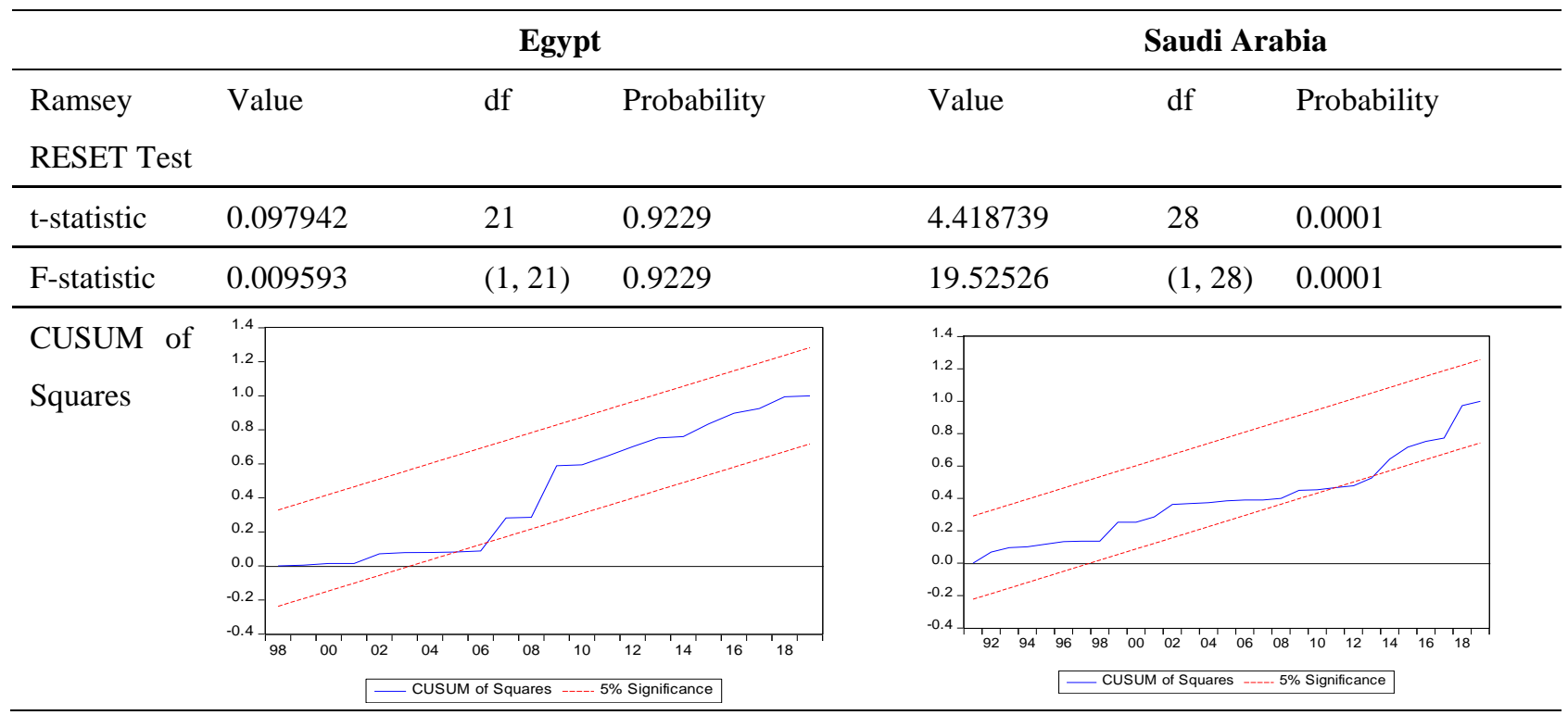

Source: Prepared by researchers using EVIEWS 10.

Table 4. Residuals Diagnostics tests

\begin{tabular}{|c|c|c|c|c|c|c|c|c|}
\hline \multirow{2}{*}{ Breusch-Godfrey Serial } & \multicolumn{4}{|c|}{ Egypt } & \multicolumn{4}{|c|}{ Saudi Arabia } \\
\hline & F-statistic & 3.27 & Prob.F $(2,20)$ & 0.06 & F-statistic & 0.557 & Prob. F $(2,27)$ & 0.579 \\
\hline Correlation LM Test & Obs*R-squared & 8.87 & Prob.Chi-Square(2) & 0.01 & Obs*R-squared & 1.507 & Prob. $\mathrm{Chi}^{2}(2)$ & 0.47 \\
\hline Heteroskedasticity & F-statistic & 1.104 & Prob.F $(13,2)$ & 0.41 & F-statistic & 0.853 & Prob. F $(8,29)$ & 0.565 \\
\hline \multirow[t]{2}{*}{ Test:Breusch-Pagan-Godfrey } & Obs*R-squared & 14.21 & Prob. Chi- $^{2}(13)$ & 0.35 & Obs*R-squared & 7.242 & Prob. Chi- $^{2}(8)$ & 0.51 \\
\hline & $\begin{array}{l}\text { Scaled explained } \\
\text { SS }\end{array}$ & 5.33 & Prob. $\mathrm{Chi}^{2}{ }^{2}(13)$ & 0.96 & $\begin{array}{l}\text { Scaled } \\
\text { explained SS }\end{array}$ & 4.333 & Prob. Chi- $^{2}(8)$ & 0.825 \\
\hline Heteroskedasticity Test: & F-statistic & 0.35 & Prob.F $(1,33)$ & 0.55 & F-statistic & 4.281 & Prob. F $(1,35)$ & 0.046 \\
\hline $\mathrm{ARCH}$ & Obs*R-squared & 0.37 & Prob. $\mathrm{Chi}^{2}{ }^{2}(1)$ & 0.54 & Obs*R-squared & 4.033 & Prob. Chi- ${ }^{2}(1)$ & 0.044 \\
\hline Jarque-Bera & 0.623032 & Prob. & 0.732336 & & Jarque-Bera & 2.076 & Prob. & 0.354 \\
\hline
\end{tabular}

Source: Prepared by researchers using EVIEWS 10.

So, there's a possibility that time series contain Structural Break, which makes previous unit root tests insufficient to determine the stability degree of the series. As existence of structural break leads to test leaning to accept null hypothesis with existence of unit root, despite correctness of alternative hypothesis (Amsler \& Lee, 1995). ADF with Structural Break test will be used to recognize the existence of structural break (Perron \& Vogelsang, 1992), as table 6 shows time series stability in Egypt to all variables (Sometimes in consistency with tests mentioned in table 3) at level $\mathrm{I}(0)$, with the exclusion of inflation rate that stayed stable at first variation $\mathrm{I}(1)$. While it was the opposite in the case of Saudi Arabia, which points out that both have structural breaks for different reasons. Egyptian economy has different activities (Agriculture, industry, etc.), while Saudi economy depends mainly on oil. 
Table 5. ADF with Structural Break test

\begin{tabular}{|c|c|c|c|c|c|c|}
\hline & \multicolumn{5}{|c|}{ Egypt } & \multirow{2}{*}{$\begin{array}{c}\text { Saudi Arabia } \\
\text { Break }\end{array}$} \\
\hline & t-Statistic & Prob* & Break & t-Statistic & Prob* & \\
\hline \multicolumn{7}{|c|}{ At Level } \\
\hline RGDP & -4.231772 & 0.3751 & 2000 & -5.935627 & $<0.01$ & 1998 \\
\hline $\mathrm{BC}$ & -1.683197 & $>0.99$ & 2004 & -5.186612 & $<0.01$ & 2000 \\
\hline LIR & -3.706901 & 0.7031 & 2016 & -7.849649 & $<0.01$ & 2007 \\
\hline INF & -5.295011 & 0.0366 & 1996 & -3.351603 & 0.4723 & 2005 \\
\hline M2 & -0.450624 & $>0.99$ & 2017 & -5.517252 & $<0.01$ & 2002 \\
\hline \multicolumn{7}{|c|}{ At First Difference } \\
\hline RGDP & -4.882723 & 0.0180 & 2018 & & & \\
\hline $\mathrm{BC}$ & -7.408442 & $<0.01$ & 1996 & & & \\
\hline LIR & -6.099809 & $<0.01$ & 1993 & & & \\
\hline INF & & & & -9.806142 & $<0.01$ & 2008 \\
\hline M2 & -5.877592 & $<0.01$ & 2008 & & & \\
\hline
\end{tabular}

*Vogelsang (1993) asymptotic one-sided p-values.

Source: Prepared by researchers using EVIEWS 10.

\subsection{Specifying Structural Breaks}

These structural breaks could e the main reason of the problems facing that model. And in order to specify the years of structural breaks, Bai-Perron (2003) Multiple Breakpoint test (Bai \& Perron, 2003) will be used. As table 7 illustrates, and according to Schwarz Criterion, the model of Egypt and Saudi Arabia contains 5 structural breaks that have taken place during the years 1986, 1992, 2001, 2008 and 2014 for Egypt. And during the years 1987, 1993, 1999, 2007 and 2013 for Saudi Arabia. It well noted that years of structural breaks starts in Egypt in 1986, followed by Saudi Arabia in 1987. Then in Egypt 1992 followed by Saudi Arabia. Afterwards, the case was reversed at the beginnings the millennial, when it's started in Saudi Arabia in 1999 then in Egypt in 2001, etc. As if test is pointing at a hidden link between Egypt \& Saudi Arabia economies, and which one is taking the lead at certain period.

Table 6. Bai-Perron Multiple Breakpoint test

\begin{tabular}{|c|c|c|c|c|c|c|c|c|c|}
\hline \multirow[b]{2}{*}{ Breaks } & \multirow[b]{2}{*}{$\begin{array}{l}\text { \# of } \\
\text { Coefs. }\end{array}$} & \multicolumn{4}{|c|}{ Egypt } & \multicolumn{4}{|c|}{ Saudi Arabia } \\
\hline & & $\begin{array}{l}\text { Sum of } \\
\text { Sq. } \\
\text { Resids. }\end{array}$ & Log-L & $\begin{array}{l}\text { Schwarz* } \\
\text { Criterion }\end{array}$ & $\begin{array}{l}\text { LWZ* }^{*} \\
\text { Criterion }\end{array}$ & $\begin{array}{l}\text { Sum of } \\
\text { Sq. } \\
\text { Resids. }\end{array}$ & Log-L & $\begin{array}{l}\text { Schwarz* } \\
\text { Criterion }\end{array}$ & $\begin{array}{l}\text { LWZ* }^{*} \\
\text { Criterion }\end{array}$ \\
\hline 0 & 5 & 3273162 & -283.00 & 11.774 & 12.025 & 632414.8 & -250 & 10.130 & 10.381 \\
\hline 1 & 11 & 205762.6 & -227.67 & 9.560 & 10.142 & 115281.5 & -216 & 8.981 & 9.563 \\
\hline 2 & 17 & 34431.8 & -191.91 & 8.326 & 9.282 & 65491.37 & -204 & 8.969 & 9.925 \\
\hline 3 & 23 & 11472.76 & -169.93 & 7.780 & 9.180 & 31278.05 & -190 & 8.783 & 10.183 \\
\hline 4 & 29 & 4747.364 & -152.28 & 7.451 & 9.429 & 19129.36 & -180 & 8.845 & 10.822 \\
\hline 5 & 35 & 4037.188 & -149.04 & 7.842 & 10.750 & 9518.701 & -166 & 8.700 & 11.608 \\
\hline \multicolumn{10}{|c|}{ Estimated break dates } \\
\hline \multicolumn{2}{|l|}{1} & \multicolumn{4}{|l|}{2011} & \multicolumn{4}{|l|}{1991} \\
\hline \multicolumn{2}{|l|}{2} & \multicolumn{4}{|c|}{$1989, \quad 2011$} & \multicolumn{4}{|c|}{$1990, \quad 2004$} \\
\hline
\end{tabular}




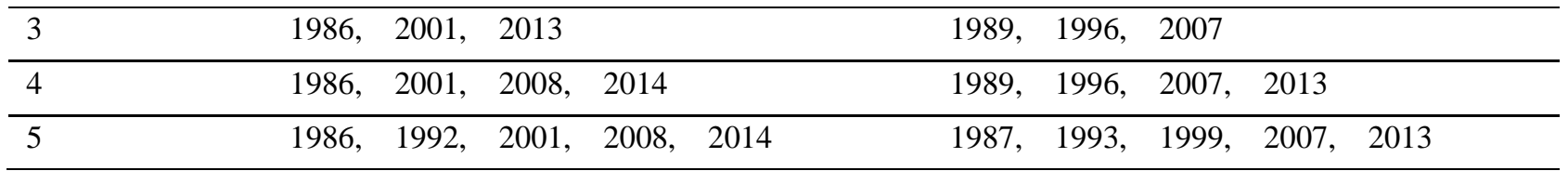

Source: Prepared by researchers using EVIEWS 10.

Breaking variables: BC LIR INF M2 C

Break test options: Trimming 0.15, Max. breaks 5

Schwarz criterion selected breaks: 4 for Egypt \& 5 for Saudi Arabia

LWZ criterion selected breaks: 3 for Egypt \& 1 for Saudi Arabia

* Minimum information criterion values displayed with shading

\subsection{Estimation of Final Model and Validity Test}

By estimating the model in its final form at three degrees of auto delay after adding five dummy variables to the years that witnessed structural breaks in order to control its effects, so it takes the value Zero (0) in previous years and the value One (1) in the year of change and the following year, considering these variables as fixed variables in order to eliminate the possibility of time delays. It turned out, with regard to instability and misspecification problem, that the estimated model doesn't have the problem of instability and misspecification. As it's shown in table 8 and according to CUSUM of Squares test for Egypt and Saudi Arabia that no regression residuals exist outside critical limits of random error. Thus, the model parameter are stable at recurrent reviews, also the insignificance of Ramsey RESET Test. Thus, the estimated model doesn't have the problem of mathematical misspecification. Table 9 of test results of residuals series of Egypt and Saudi Arabia models shows that the models don't suffer from autocorrelation and heteroscedasticity, and both follow the normal distribution. Thus, both are clear of standard problems related to random limit characteristics. And both have Econometric Robustness, so model can be used in estimating the relation between variables on both the short and long term.

Table 7. Stability tests for final model

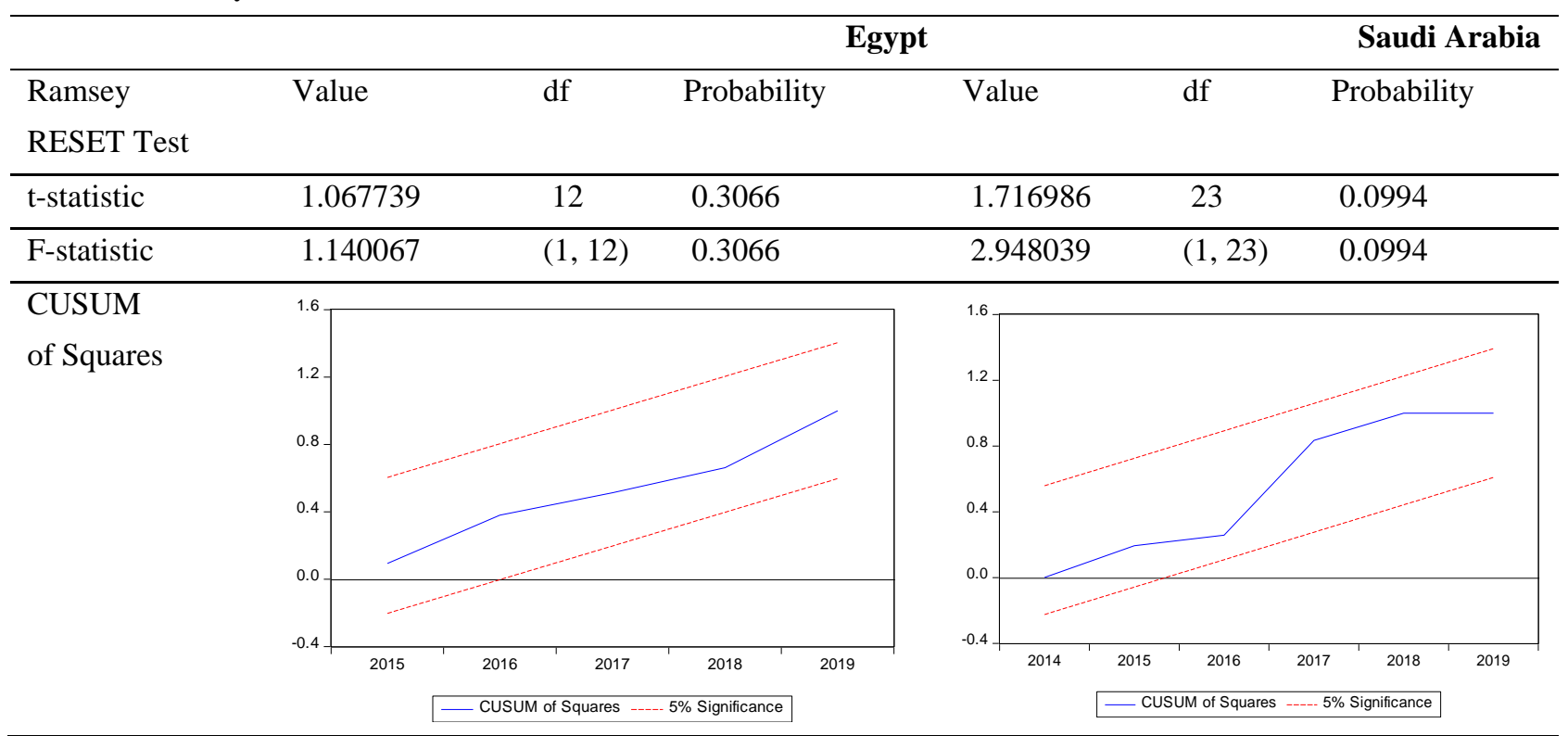

Source: Prepared by researchers using EVIEWS 10. 
Table 8. Residuals Diagnostics tests for final model

\begin{tabular}{|c|c|c|c|c|c|c|c|c|}
\hline \multirow{3}{*}{$\begin{array}{l}\text { Breusch-Godfrey } \\
\text { Serial Correlation } \\
\text { LM Test }\end{array}$} & \multicolumn{4}{|c|}{ Egypt } & \multicolumn{4}{|c|}{ Saudi Arabia } \\
\hline & F-statistic & 0.517 & $\begin{array}{l}\text { Prob. } \\
\mathrm{F}(2,11)\end{array}$ & 0.61 & F-statistic & 1.783 & $\begin{array}{l}\text { Prob. } \\
\mathrm{F}(2,22)\end{array}$ & 0.192 \\
\hline & Obs*R-squared & 3.178 & $\begin{array}{l}\text { Prob. } \\
\text { Chi- }^{2}(2)\end{array}$ & 0.20 & Obs*R-squared & 5.299 & Prob. Chi- $^{2}$ & 0.071 \\
\hline \multirow{3}{*}{$\begin{array}{l}\text { Heteroskedasticity } \\
\text { Test: Breusch- } \\
\text { Pagan-Godfrey }\end{array}$} & F-statistic & 0.787 & $\begin{array}{l}\text { Prob. } \\
\text { F }(23,13)\end{array}$ & 0.70 & F-statistic & 0.637 & $\begin{array}{l}\text { Prob. } \\
F(13,24)\end{array}$ & 0.800 \\
\hline & Obs*R-squared & $\begin{array}{l}21.53 \\
6\end{array}$ & $\begin{array}{l}\text { Prob. } \\
\text { Chi- }^{2} \text { (23) }\end{array}$ & 0.55 & Obs*R-squared & 9.750 & $\begin{array}{l}\text { Prob. } \text { Chi- }^{2} \\
\text { (13) }\end{array}$ & 0.714 \\
\hline & $\begin{array}{l}\text { Scaled } \\
\text { explained SS }\end{array}$ & 2.285 & $\begin{array}{l}\text { Prob. } \\
\text { Chi- }^{2} \text { (23) }\end{array}$ & 1.00 & $\begin{array}{l}\text { Scaled } \\
\text { explained SS }\end{array}$ & 5.022 & $\begin{array}{l}\text { Prob. } \text { Chi- }^{2} \\
\text { (13) }\end{array}$ & 0.975 \\
\hline \multirow[t]{2}{*}{$\begin{array}{l}\text { Heteroskedasticity } \\
\text { Test: ARCH }\end{array}$} & F-statistic & 0.517 & $\begin{array}{l}\text { Prob. } \\
\mathrm{F}(1,34)\end{array}$ & 0.48 & F-statistic & 0.051 & $\begin{array}{l}\text { Prob. } \\
\mathrm{F}(1,35)\end{array}$ & 0.823 \\
\hline & F-statistic & 0.517 & $\begin{array}{l}\text { Prob. } \\
\mathrm{F}(1,34)\end{array}$ & 0.48 & Obs*R-squared & 0.054 & $\begin{array}{l}\text { Prob. } \\
\text { Chi- }^{-}(1)\end{array}$ & 0.816 \\
\hline Jarque-Bera & 1.033 & Prob. & 0.596 & & Jarque-Bera & 2.458 & Prob. & 0.292 \\
\hline
\end{tabular}

Source: Prepared by researchers using EVIEWS 10.

\subsection{Cointegration Test Using Bound Test}

Using cointegration between dependent and independent variables according to autoregression model for Autoregressive-Distributed Lag, using the bound test, Table (10) F-Bound Test shows that calculated F value is higher than maximum Critical Values if the test at different significance levels. Thus, the null hypotheses si rejected due to absence of a long-run equilibrium relationship between study variables, while the alternative hypotheses is accepted. Thus, study variables are linked through cointegration relation that moves from independent variables jointly to dependent variable.

Table 9. F-Bounds Test for final model

\begin{tabular}{lllll}
\hline Egypt & Saudi Arabia & Signif. & I(0) & I(1) \\
\hline Value & Value & & & 3.53 \\
\hline 5.718944 & 13.55159 & $10 \%$ & 2.68 & 3.97 \\
\hline & $5 \%$ & 3.05 & 4.36 \\
\hline & $2.5 \%$ & 3.4 & 4.92 \\
\hline
\end{tabular}

Source: Prepared by researchers using EVIEWS 10.

\subsection{Estimating Relationship Between Long-Run Model Variables}

By estimating parameters of independent variables relation with dependent variables in the long run, table 11 shows the statistical significance of the relation between lending interest rate at 5\% level for Egypt model, which has a statistically significant and inverse relation with dependent variable that represent economic growth level. Parameter value has been estimated by around -63.84 , which means that the increase in lending interest rate by around $1 \%$ leads to a decrease in gross domestic product with fixed prices of approximately 63.84 billion EGP. While Saudi Arabia has fixed statistic significance of lending interest rate, and inflation rate at 5\%, as lending interest rate has an statistically significance and inverse relationship with dependent variable that represent economic growth level, in the long-run. Parameter value has been estimated by around -240.36 , which means that the increase in lending 
interest rate by around $1 \%$ will lead to decrease in gross domestic product in fixed rates with approximately 240.36 billion SAR. Inflation rate variable has a statistically significant and direct relationship with dependent variable representing economic growth. Parameter value has been estimated by around 28.50 , which means that the increase in lending interest rate by around $1 \%$ will lead to an increase in gross domestic product in fixed rates with approximately 28.50 billion SAR.

And explains inverse relationship of lending interest rate effect, where its increase leads to a decrease in investors' lending because of the increase in capital Marginal Efficiency of Capital, then a relapse in various sectors development then a decrease in real gross domestic product and a shrinking in economic growth. As investor compares the lending interest rate with ponds and stocks prices, that way they pull away from expanding in production. While it explains the direct relationship between inflation rate and economic growth to fiscal policy, where expansive fiscal policy to an increase in banks credits that offers loans to investors in order to encourage them to invest, thus increases production which in turn triggers economic growth. These conclusions go in line with perspective of economic theory and numerous previous studies.

Table 10. Long Run Form for final model

\begin{tabular}{|c|c|c|c|c|c|c|c|c|}
\hline & \multicolumn{4}{|c|}{ Egypt } & \multicolumn{4}{|c|}{ Saudi Arabia } \\
\hline Variable & Coefficient & $\begin{array}{l}\text { Std. } \\
\text { Error }\end{array}$ & t-Statistic & Prob. & Coefficient & $\begin{array}{l}\text { Std. } \\
\text { Error }\end{array}$ & t-Statistic & Prob. \\
\hline $\mathrm{BC}$ & 2.755 & 1.776 & 1.551 & 0.145 & 0.203 & 0.143 & 1.418 & 0.169 \\
\hline LIR & -63.843 & 24.813 & -2.573 & 0.023 & -240.361 & 96.538 & -2.490 & 0.020 \\
\hline INF & 46.339 & 21.981 & 2.108 & 0.055 & 28.496 & 10.263 & 2.777 & 0.011 \\
\hline M2 & -2.621 & 1.835 & -1.428 & 0.177 & -0.198 & 0.382 & -0.520 & 0.608 \\
\hline @TREND & 102.376 & 25.042 & 4.088 & 0.001 & 67.093 & 18.834 & 3.562 & 0.002 \\
\hline & \multicolumn{4}{|c|}{$\begin{array}{l}\mathrm{EC}=\mathrm{RGDP}-(2.7549 * \mathrm{BC}-63.8428 * \mathrm{LIR}+ \\
46.3393 * \mathrm{INF}-2.6206 * \mathrm{M} 2+102.3756\end{array}$} & \multicolumn{4}{|c|}{$\begin{array}{l}\mathrm{EC}=\mathrm{RGDP}-(0.2034 * \mathrm{BC} \quad-240.3612 * \mathrm{LIR}+ \\
28.4965 * \mathrm{INF}-0.1984 * \mathrm{M} 2+67.0926\end{array}$} \\
\hline & \multicolumn{4}{|l|}{ *@TREND ) } & \multicolumn{4}{|c|}{ *@TREND ) } \\
\hline
\end{tabular}

Source: Prepared by researchers using EVIEWS 10.

\subsection{Estimating Unrestricted Error Correction Model (UECM)}

Depending on SB Schwarz criterion, which is favored in Autoregressive-Distributed Lag for being suitable for small samples, lag durations have been auto distributed among study variables. Model $(3,3,3,3,1)$ has been chosen as the best model for Egypt, while $(1,0,2,0,0)$ was chosen as the best model for Saudi Arabia. Table 12 shows, for Egypt, the statistic significance for first variance of gross domestic product variable in two delay periods, banking credit, first variance of banking credit in one delay period, first variance of banking credit in two delay periods, lending interest rate, first variance of lending interest rate in one delay period, inflation rate, first variance of inflation rate in one delay period and first variance of inflation rate in two delay periods, this is on the short run. While dummy variables that represent structural breaks had a statistically significant and inverse relation for the years 1986 and 2001. Error correction term has been estimated by -0.30 , which is negative and statistically significant. Thus, $30 \%$ of short-term errors were corrected during one time unit, so short-term errors are corrected in 3.33 years.

As for Saudi Arabia, statistically significance has been proven for both first variance of lending interest rate variable, first variance of lending interest rate variable with one delay period, on the short term. While dummy variables that represent structural breaks had an inverse and statistically significant relationship for the years 1993 and 1999, and a direct relationship for 2007. Error correction term has been estimated by -0.48 , which is negative and statistically significant. Thus, $48 \%$ of short-term errors were corrected during one time unit, so short-term errors are corrected in 2.08 years.

It must be put in mind that the relationship between variables may not represent causal relationship, as it could be a synchronous movement, unless it is proved by a causality test. 
Table 11. ARDL Error Correction Regression for final model

\begin{tabular}{llllllllll}
\hline \multicolumn{7}{c}{ Egypt } & \multicolumn{7}{c}{ Saudi Arabia } \\
\hline Variable & Coeff. & S. Error & t-St. & Prob. & Variable & Coeff & Std. Error & t-St. & Prob. \\
\hline C & 244.91 & 33.46 & 7.32 & 0.00 & C & 570.447 & 69.18 & 8.245 & 0.00 \\
\hline D(RGDP(-1)) & 0.05 & 0.12 & 0.44 & 0.66 & & & & & \\
\hline D(RGDP(-2)) & 0.43 & 0.14 & 3.01 & 0.01 & & & & & \\
\hline D(BC) & -0.22 & 0.09 & -2.36 & 0.03 & & & & & \\
\hline D(BC(-1)) & -0.74 & 0.12 & -6.48 & 0.00 & & & & & \\
\hline D(BC(-2)) & -0.20 & 0.05 & -3.74 & 0.00 & & & & & \\
\hline D(LIR) & -18.20 & 5.95 & -3.06 & 0.00 & D(LIR) & -50.773 & 10.97 & -4.62 & 0.00 \\
\hline D(LIR(-1)) & 15.94 & 5.79 & 2.75 & 0.01 & D(LIR(-1)) & 54.403 & 11.07 & 4.912 & 0.00 \\
\hline D(LIR(-2)) & -6.23 & 4.35 & -1.43 & 0.17 & & & & & \\
\hline D(INF) & 5.79 & 1.10 & 5.27 & 0.00 & & & & & \\
\hline D(INF(-1) $)$ & -5.13 & 1.28 & -4.02 & 0.00 & & & & & \\
\hline D(INF(-2) $)$ & -3.209 & 1.060 & -3.02 & 0.01 & & & & & \\
\hline D(M2) & 0.140 & 0.128 & 1.088 & 0.29 & & & & & \\
\hline DUM1986 & -94.55 & 17.142 & -5.51 & 0.000 & DUM1987 & -66.878 & 33.972 & -1.96 & 0.061 \\
\hline DUM1992 & 13.538 & 14.089 & 0.961 & 0.354 & DUM1993 & -96.126 & 24.494 & -3.92 & 0.001 \\
\hline DUM2001 & -53.22 & 13.049 & -4.07 & 0.001 & DUM1999 & -126.21 & 27.801 & -4.54 & 0.000 \\
\hline DUM2008 & 25.081 & 15.716 & 1.596 & 0.135 & DUM2007 & 110.471 & 23.696 & 4.662 & 0.000 \\
\hline DUM2014 & 41.593 & 28.606 & 1.454 & 0.170 & DUM2013 & -3.875 & 23.982 & -0.16 & 0.873 \\
\hline CointEq(-1) & -0.296 & 0.043 & -6.89 & 0.000 & CointEq(-1) & -0.477 & 0.048 & -9.91 & 0.000 \\
\hline
\end{tabular}

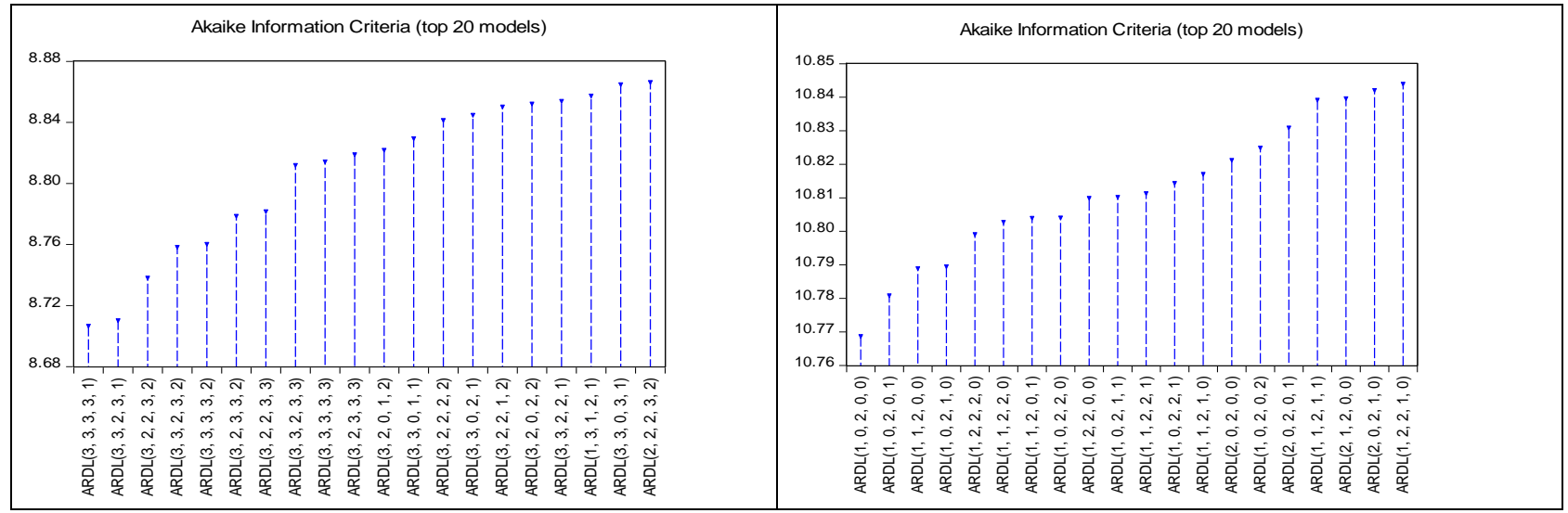

Source: Prepared by researchers using EVIEWS 10.

\subsection{Testing for Long-Run Causality}

In order to test causality relationship between study variables in the long-run, Toda \& Yamamoto (1995) (Toda \& Yamamoto, 1995) methodology has been used. Which depends on Augmented VAR model to know the Maximal integration order "dmax" of the time series, then number of optimal delay periods for study variables is specified depending on the normal VAR model. According to table 13 and Schwarz criterion, the number of optimal delays for study variables equals $\mathrm{P}=5$, then Augmented VAR model is estimated under some limits on parameters matrix (P+dmax). 
Table 12. VAR Lag Order Selection Criteria for final model

\begin{tabular}{|c|c|c|c|c|c|c|c|c|c|c|c|c|}
\hline \multirow{2}{*}{ Lag } & \multicolumn{6}{|c|}{ Egypt } & \multicolumn{6}{|c|}{ Saudi Arabia } \\
\hline & $\overline{\log L}$ & LR & FPE & AIC & $\mathrm{SC}$ & HQ & $\log L$ & LR & FPE & $\mathrm{AIC}$ & $\mathrm{SC}$ & HQ \\
\hline$\overline{0}$ & -930.049 & $8 \mathrm{NA}$ & $1.10 \mathrm{e}+17$ & 53.43 & 53.65 & 53.51 & -860.196 & $8 \mathrm{NA}$ & $2.04 \mathrm{e}+15$ & 49.43982 & 49.66201 & 49.51652 \\
\hline 1 & -687.2 & 402.4 & $4.40 \mathrm{e}+11$ & 40.98 & 42.32 & 41.44 & -666.7 & 320.7 & $1.36 \mathrm{e}+11$ & 39.81 & 41.14 & 40.27 \\
\hline 2 & -634.8 & 71.9 & $1.01 \mathrm{e}+11$ & 39.42 & 41.86 & 40.26 & -640.2 & 36.3 & $1.37 e+11$ & 39.73 & 42.17 & 40.57 \\
\hline 3 & -591.7 & 46.8 & $4.62 \mathrm{e}+10$ & 38.38 & 41.94 & 39.61 & -607.1 & 36.0 & $1.12 \mathrm{e}+11$ & 39.26 & 42.82 & 40.49 \\
\hline 4 & -546.5 & 36.1 & $2.57 \mathrm{e}+1$ & 37.23 & 41.89 & 38.84 & -538.3 & $54.99 *$ & $1.61 \mathrm{e}+10$ & 36.76 & 41.43 & 38.37 \\
\hline 5 & -454.4 & $47.35^{*}$ & $1.86 \mathrm{e}+09 *$ & $* 33.39 *$ & $39.17 *$ & $35.38 *$ & -479.5 & 30.3 & $7.79 \mathrm{e}+09 *$ & $* 34.82 *$ & $40.60 *$ & $36.82 *$ \\
\hline
\end{tabular}

* indicates lag order selected by the criterion

LR: sequential modified LR test statistic (each test at 5\% level), FPE: Final prediction error, AIC: Akaike information criterion, SC: Schwarz information criterion \& HQ: Hannan-Quinn information criterion

Source: Prepared by researchers using EVIEWS 10.

Afterwards, causality relation between study variables is tested, as shown in table 14, lending interest offer and money supply are linked with a long-term causality relationship in one direction with gross domestic product as representative to economic growth. And in consequence, they both cause economic growth, but economic growth does not cause them or any of the other variables in the case of Egypt, and lending interest rate is linked with gross domestic product as representative to economic growth in a long-term causality relationship. And in consequence, it causes economic growth, but economic growth does not cause it or any of the other variables ion the case of Saudi Arabia. In light of conclusions of Tables $11 \& 14$, lending interest rate is the only variable that affects gross domestic product (Inverse relationship) with is linked to it with a causality relationship. So, It's the only variable that can trigger economic growth for both Egypt and Saudi Arabia, despite the differences in structure and economic variety for both countries.

Table 13. Residuals Diagnostics tests for final model

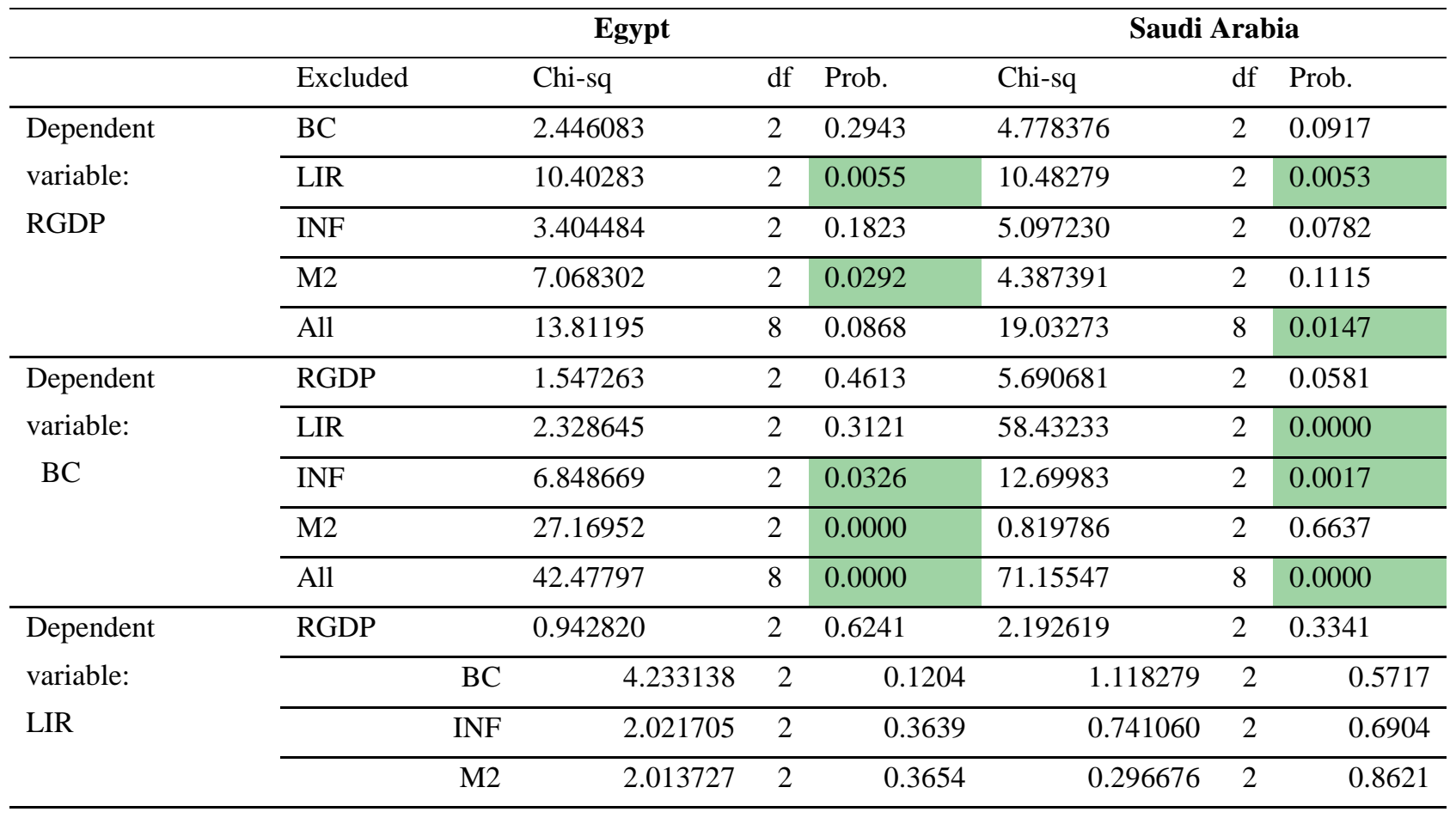




\begin{tabular}{llllllll}
\hline & All & 18.03807 & 8 & 0.0209 & 7.845719 & 8 & 0.4487 \\
\hline $\begin{array}{l}\text { Dependent } \\
\text { variable: }\end{array}$ & RGDP & 4.295053 & 2 & 0.1168 & 4.408704 & 2 & 0.1103 \\
\cline { 2 - 7 } INF & BC & 2.991005 & 2 & 0.2241 & 3.548125 & 2 & 0.1696 \\
\cline { 2 - 7 } & LIR & 0.193793 & 2 & 0.9077 & 3.245271 & 2 & 0.1974 \\
\cline { 2 - 7 } & M2 & 8.615019 & 2 & 0.0135 & 9.690639 & 2 & 0.0079 \\
\cline { 2 - 7 } & All & 29.00821 & 8 & 0.0003 & 20.87079 & 8 & 0.0075 \\
\hline $\begin{array}{l}\text { Dependent } \\
\text { Mariable: }\end{array}$ & RGDP & 2.079559 & 2 & 0.3535 & 1.888058 & 2 & 0.3891 \\
\cline { 2 - 7 } & BC & 25.88800 & 2 & 0.0000 & 15.56220 & 2 & 0.0004 \\
\cline { 2 - 7 } & LIR & 1.762901 & 2 & 0.4142 & 8.584673 & 2 & 0.0137 \\
\cline { 2 - 7 } & INF & 4.681815 & 2 & 0.0962 & 2.928516 & 2 & 0.2312 \\
\cline { 2 - 7 } & All & 47.41391 & 8 & 0.0000 & 22.88815 & 8 & 0.0035 \\
\hline
\end{tabular}

Source: Prepared by researchers using EVIEWS 10.

\section{Discussion}

The research is basically aiming at measuring and analyzing the effect of financial development on economic growth, through measuring the short-term and long-term relation among financial development variables and economic growth in a comparative study between Egypt and Saudi Arabia. Considering that both countries are different with regard to the pillars they depend on to affect economic growth, using annual data represent the period (1980-2018). Autoregressive Distributed Lag Model (ARDL) methodology has been used after being processed from structural breaks by adding 5 dummy variables that represent that dates in which changes have taken place, with affirmation on model's standard sturdiness. Bounds test has proven the existence of long-term equilibrium relation, this way study variables are connected through cointegration relationship that moves from independent variables to dependent variable all at one time. It turned out there's a statistically significant inverse relationship at level $5 \%$ between lending interest rate and dependent variable that represents the level of Egypt's model economic growth. It was estimated by around -63.84 , which means that any increase in lending interest rate by around $1 \%$ leads to a decrease in gross domestic product in fixed rates by around 36.84 billion EGP. As for Saudi Arabia, statistic significance has been proven for lending interest rate and inflation rate at level 5\%, where lending interest rate is linked to dependent variable representing economic growth level through an inverse relationship, it was estimated by around -240.36 . Which means, any increase in lending interest rate by $1 \%$ leads to a drop in gross domestic product with fixed rates by around 240.36 billion SR. While inflation rate variable is linked with dependent variable representing economic growth by a direct relationship that was estimated by 28.50 . This means that any increase in inflation rate by around $1 \%$ leads to an increase in gross domestic product with fixed rates by around 28.50 billion SR. Egypt's error correction limit was estimated by around -0.30 , which is statistically significant and negative, this way $30 \%$ of short-term errors are corrected in one time unit, so short-term errors are corrected in 3.33 years. Also, Saudi Arabia's error correction limit was estimated by -0.48 , which is statistically significant and negative, this way $48 \%$ of short-term errors are corrected during one time unit, so short-term errors should be corrected in 2.08 years. The final and important conclusion of the research is that lending interest rate is the only variable affecting gross domestic product (Inverse relationship) which is linked to it through a causality relationship. Thus, it's the only variable that can lead economic growth in both Egypt and Saudi Arabia, despite the difference in structure and economic variety of both countries. The research recommends:

- Lending interest rate must be decreased in order to encourage investors to take loans to spend in investments, which triggers the economic growth.

- Not to depend on one actual variable, which is lending interest rate, in affecting and guiding economic growth. Instead, several other tools must be considered.

\section{References}

Adamopoulos, A. (2010). Financial development and economic growth an empirical analysis for Ireland. International Journal of Economic Sciences and Applied Research, 3(1), 75-88. 
Amsler, C., \& Lee, J. (1995). An LM test for a unit root in the presence of a structural change. Econometric Theory, 11(2), 359-368. https://doi.org/10.1017/S026646660000921X

Antonios, A. (2010). Credit market development and economic growth: an empirical analysis for Ireland. European Research Studies, XIII(4), 3-18. https://doi.org/10.35808/ersj/296

Bai, J., \& Perron, P. (2003). Computation and analysis of multiple structural change models. Journal of Applied Econometrics, 18(1), 1-22. https://doi.org/10.1002/jae.659

Breusch, T. S. (1978). Testing for autocorrelation in dynamic linear models. Australian Economic Papers, 17(31), 334-355. https://doi.org/10.1111/j.1467-8454.1978.tb00635.x

Breusch, T. S., \& Pagan, A. R. (1979). A simple test for heteroscedasticity and random coefficient variation. Econometrica: Journal of the Econometric Society, 47(5), 1287-1294. https://doi.org/10.2307/1911963

Dolar, V., \& Meh, C. (2002). Financial structure and economic growth: A non-technical survey (pp. 02-24). Monetary and Financial Analysis Department, Bank of Canada.

Dritsakis, N., \& Adamopoulos, A. (2004). Financial development and economic growth in Greece: An empirical investigation with Granger causality analysis. International Economic Journal, 18(4), 547-559. https://doi.org/10.1080/1016873042000299981

Duican, E. R., \& Pop, A. (2015). The implications of credit activity on economic growth in Romania. Procedia Economics and Finance, 30, 195-201. https://doi.org/10.1016/S2212-5671(15)01286-1

Engle, R. F. (1982). Autoregressive conditional heteroscedasticity with estimates of the variance of United Kingdom inflation. Econometrica: Journal of the Econometric Society, 50(4), 987-1007. https://doi.org/10.2307/1912773

Fedorová, D. (2016). Selection of unit root test on the basis of length of the time series and value of ar (1) parameter. Statistika, 96(3), 47-64.

Furqani, H., \& Mulyany, R. (2009). Islamic banking and economic growth: Empirical evidence from Malaysia. Journal of Economic Cooperation \& Development, 30(2), 59-74.

Gautam, B. P. (2014). Financial development and economic growth in Nepal (Vol. NRB Working Paper No. 25). Nepal Rastra Bank, Research Department.

Guptha, K. S. K., \& Rao, R. P. (2018). The causal relationship between financial development and economic growth: an experience with BRICS economies. Journal of Social and Economic Development, 20(2), 308-326. https://doi.org/10.1007/s40847-018-0071-5

International Monetary Fund, International Financial Statistics. Retrieved from https://data.albankaldawli.org/country

Judith, M. N., Ugwuegbe, S., \& Ugwuoke, R. (2014). The impact of bank credit on the growth of Nigerian economy: A co integration approach. Research Journal of Finance and Accounting, 5(10), 87-95.

Lee, C.-C., \& Chien, M.-S. (2008). Structural breaks, tourism development, and economic growth: Evidence from Taiwan. Mathematics and Computers in Simulation, 77(4), 358-368. https://doi.org/10.1016/j.matcom.2007.03.004

Leitão, N. C. (2012). Bank credit and economic growth: A dynamic panel data analysis. Economic Research Guardian, 2(2), 256-267.

Levine, R. (2005). Finance and growth: theory and evidence. Handbook of Economic Growth, 1, 865-934. https://doi.org/10.1016/S1574-0684(05)01012-9

Lucas Jr, R. E. (1988). On the mechanics of economic development. Journal of Monetary Economics, 22(1), 3-42. https://doi.org/10.1016/0304-3932(88)90168-7

Mohanty, A., Kumar, S., \& Patra, S. (2016). Bank credit and economic growth: An empirical evidence from Indian states. International Journal of Current Research, 8(9), 39145-39151.

Musamali, R. A., Nyamongo, E. M., \& Moyi, E. D. (2014). The relationship between financial development and economic growth in Africa. Research in Applied Economics, 6(2), 190-208. https://doi.org/10.5296/rae.v6i2.5226

Mwang'onda, E., Mwaseba, S. L., \& Ngwilizi, D. N. (2018). Impact of Financial Sector Development on Economic Growth: Evidence from Tanzania. International Journal of Economics and Financial Research, 4(8), 258-265. 
National accounts data for the World Bank, and data for national accounts for the Organization for Economic Cooperation and Development. Retrieved from https://data.albankaldawli.org/country

Odhiambo, N. M. (2005). Financial development and economic growth in Tanzania: A dynamic causality test. African Finance Journal, 7(1), 1-17.

Ogunyiola, A. (2013). Financial development and economic growth: The case of Cape Verde.

Osman, E. G. A. (2014). The impact of private sector credit on Saudi Arabia Economic Growth (GDP): An Econometrics model using (ARDL) Approach to Cointegration. Am Int J Soc Sci, 3(6), 109-117.

Perera, N., \& Paudel, R. C. (2009). Financial development and economic growth in Sri Lanka.

Perron, P., \& Vogelsang, T. J. (1992). Nonstationarity and level shifts with an application to purchasing power parity. Journal of Business \& Economic Statistics, 10(3), 301-320. https://doi.org/10.1080/07350015.1992.10509907

Pesaran, M. H., \& Shin, Y. (1995). An autoregressive distributed lag modelling approach to cointegration analysis.

Pesaran, M. H., Shin, Y., \& Smith, R. J. (2001). Bounds testing approaches to the analysis of level relationships. Journal of Applied Econometrics, 16(3), 289-326. https://doi.org/10.1002/jae.616

Ramsey, J. B. (1969). Tests for specification errors in classical linear least-squares regression analysis. Journal of the Royal Statistical Society: Series B (Methodological), 31(2), 350-371. https://doi.org/10.1111/j.2517-6161.1969.tb00796.x

Robinson, J. (1979). The generalisation of the general theory The Generalisation of the General Theory and Other Essays (pp. 1-76). Springer. https://doi.org/10.1007/978-1-349-16188-1

Rostow, W. (1974). Money and Capital in Economic Development. By Ronald I. McKinnon. (Washington, DC: The Brookings Institution, 1973. Pp. 184. \$7.50.). American Political Science Review, 68(4), 1822-1824. https://doi.org/10.2307/1960040

Shaheen, S., Awan, M. S., Waqas, M., \& Aslam, M. A. (2011). Financial development, international trade and economic growth: Empirical evidence from Pakistan.

Tabash, M. I., \& Dhankar, R. S. (2014). Islamic Financial Development and Economic Growth--Empirical Evidence from United Arab Emirates. Journal of Emerging Economies and Islamic Research, 2(3), 15-31. https://doi.org/10.24191/jeeir.v2i3.9630

Tahir, S. H., Shehzadi, I., Ali, I., \& Ullah, M. R. (2015). Impact of bank lending on economics growth in Pakistan: an empirical study of lending to private sector. American Journal of Industrial and Business Management, 5(8), 565. https://doi.org/10.4236/ajibm.2015.58056

Toda, H. Y., \& Yamamoto, T. (1995). Statistical inference in vector autoregressions with possibly integrated processes. Journal of econometrics, 66(1-2), 225-250. https://doi.org/10.1016/0304-4076(94)01616-8

Uttam Paudel, S. C. B., \& Khatri, U. (2018). Financial Development and Economic Growth in Nepal: New intuitions from a Time Series Causality Method. Journal of Social Sciences, 14(1), 116-123. https://doi.org/10.3844/jssp.2018.116.123

Vaithilingam, S., Guru, B. K., \& Shanmugam, B. (2003). Bank lending and economic growth in Malaysia. Journal of Asia-Pacific Business, 5(1), 51-69. https://doi.org/10.1300/J098v05n01_05

\section{Copyrights}

Copyright for this article is retained by the author(s), with first publication rights granted to the journal.

This is an open-access article distributed under the terms and conditions of the Creative Commons Attribution license (http://creativecommons.org/licenses/by/4.0/). 